\title{
MARKET RESEARCH CONCERNING FUNCTIONAL AND MATERIAL SOLUTIONS EMPLOYED IN NURSERY FACILITIES
}

\author{
E. RADZISZEWSKA-ZIELINA ${ }^{1}$, W. GRABOWSKA ${ }^{2}$, B. SZEWCZYK ${ }^{3}$
}

\begin{abstract}
A great number of non-functional child care facilities for children up to the age of three have been created in Poland to this day. This state of affairs may be the consequence of the low level of knowledge in this field, as well as few available studies on topics associated with nursery facilities, which may familiarise readers with the legal aspects, administrative procedures, or examples of good functional and material solutions of such units. What is more, there is also little information about the needs and preferences of people directly related to the topic. The aim of the article is to analyse the expectations and preferences of nursery facilities' users in terms of the functional and material solutions. Based on a survey conducted among the nurseries' employees and parents placing their children in the care of such institutions, a number of guidelines has been defined, allowing for the design of an optimal nursery facility that would meet the market's expectations.
\end{abstract}

Keywords: market research, nursery facilities, functional and material solutions, finishing materials for floors.

\section{INTRODUCTION}

The functioning of child care facilities for children under the age of three is regulated by the law [14]. The number of places in nurseries did not use to satisfy the growing demand, which, consequently, resulted in lessening of the technical requirements for nurseries. As a result, many

\footnotetext{
${ }^{1}$ Assoc. Prof. PhD. Eng., Cracow University of Technology, Faculty of Civil Engineering, ul. Warszawska 24, 31-155 Cracow, Poland, e-mail: eradzisz@izwbit.pk.edu.pl

${ }^{2}$ MSc. Eng., Foundation for the Promotion of Artistic Education, ul. Ks. Józefa Kurzei 17/7,31-618 Cracow, Poland ${ }^{2}$ Dr, Eng., Cracow University of Technology, Faculty of Civil Engineering, ul. Warszawska 24, 31-155 Cracow, Poland
} 
non-functional childcare facilities for children up to the age of three have been established. Extreme cases include facilities that do not meet the provisions of the construction law, good design practice, not to mention the expectations of the employees or the parents of the children attending them. Poorlydesigned units are primarily a problem for their youngest users. This state of affairs may be the consequence of the low level of knowledge in this field, as well as few available studies on topics associated with nursery facilities, which may familiarise readers with the legal aspects, administrative procedures, or examples of good functional and material solutions of such units. What is more, there is also little information about the needs and preferences of people directly related to the topic. There is a need for research in this area, as well as for good interdisciplinary cooperation while the nursery construction projects are being carried out, all based on partnership relations [7, 11, 12]. Public buildings in which the nurseries are located usually undergo numerous modernisation processes over the course of their entire usage. Assessing the condition of the structure, especially regarding any changes to the function of individual rooms, is a crucial issue. It is associated with necessary changes in the structure's architectural and structural layout meant to provide a safe environment, which would meet the high demands of its future users - children [7, 8]. In addition, the financial aspect plays a significant role: the high costs of maintaining nurseries set up by public developers and low project's profitability in the private sector result in a lack of funds for consultations with experts such as interior designers. The obstacle in the development of nurseries is, among other factors, the lack of sufficient financial resources to maintain these institutions [4]. Ministerial programmes, the EU's and local cofinancing for the stay of children in the facilities have been implemented for years in order to tackle this issue. Thanks to nursery development support programmes, the problem of the low profitability of these projects and their high maintenance costs are gradually being addressed. In the article [8] the authors emphasize that the division of space in nurseries into smaller rooms is beneficial in the process of children's education thanks to the provision into smaller units. Consequently, more intimate contact between the staff and those under care is possible. The authors of the publication [9], in turn, present the participatory design approach used in the public sector in Sweden to achieve the goals of sustainable development and meet the stakeholders' requirements more successfully. An example such approach was used is presented, among others, when designing furniture and textiles for the nursery. Its staff, the parents and council officers participated in the process. The article [2] presents the results of research, suggesting that the characteristics of the building, including the flooring materials employed in it, can partly explain increases in asthma and allergy cases among the children. The selection of finishing materials in the nurseries is therefore a significant issue. 
The aim of the article is to analyse the expectations and preferences of such institutions' users, paying special attention to the functional and material solutions, based on the opinion of the employees and parents entrusting their children to the care of these institutions.

\section{RESEARCH PROBLEM}

The research problem was to determine the expectations of nursery users in the area of the function of nursery spaces, the functional arrangement of spaces and material solutions.

The first research group consisted of employees of nurseries located in the city of Krakow in Poland, carers and teachers working at nurseries on a daily basis and using their infrastructure. The second research group were parents of children attending these nurseries.

An online survey was chosen to perform the study. Based on the Krakow Family Guidebook [5], a list of nurseries operating in the city had been compiled and then a mailing list was created. Appropriate messages were sent to the nurseries' directors with a request to participate in the survey and send out a questionnaire to employees and parents [3].

\section{SAMPLE SIZE DETERMINATION}

The size of the sample including carers and teachers and the size of the sample featuring the parents of attending children at Krakow nurseries were determined with knowledge of the size of the population. The website of the City of Krakow [15] provides data on the number of children covered by childcare in 2017 in Krakow, which amounted to 7,142 children, as well as data on the number of people who worked in institutional forms of child care over in 2017, which was 890 people. The sample size for a finite population is determined using formula (3.1).

$$
n=\frac{P(1-P)}{\frac{e^{2}}{z^{2}}+\frac{P(1-P)}{N}}
$$

where:

$n$ - sample size, $N$ - population size, $P$ - estimated fraction, $e$ - admissible error, $z$-number of standard deviations resulting from Student distribution for the assumed confidence level 
Since a confidence level of $95 \%$ was assumed, with values $e=0.1, z=1.96, N=890, P=50 \%$, the calculated sample size was $n=87$.The size of the sample in the case of parents of children attending the nurseries was determined in an analogous manner $(n=95)$. The survey was discontinued after collecting the opinions of 100 employees and 100 parents.

\section{RESULTS}

\subsection{PREFERRED FUNCTIONAL ARRANGEMENT OF ROOMS}

In the case of projects featuring the establishment of nurseries, it is important to ensure well-thought out and defined types of spaces, their function and layout. The survey questions were structured in such a way that it was possible to compare the current functional layout of nursery facilities with the preferences of employees and parents. Upon analysing the results of the study (Fig. 1) it can be stated that the preferences of teachers and parents regarding the functional layout of nursery facilities are slightly different.

The children's room is a space where children and employees spend the majority of the time spent at nurseries. Only $26 \%$ of teachers worked at nurseries in which each of the rooms was connected with the cloakroom, while as many as $85 \%$ of teachers expected such a solution. The extant conditions in nurseries regarding the connection of the room with the garden are were line with teachers' preferences. In turn, $35 \%$ of teachers worked in a nursery, in which each room was connected to a bathroom, while $92 \%$ of teachers expected such a solution. The answer to the next question brought a surprising result. As many as $54 \%$ of teachers worked in a nursery, where the children's room was connected to the kitchen, with only $18 \%$ preferring such a connection.

In turn, the analysis of parents' preferences concerning the interrelations between rooms showed that $85 \%$ of parents expected children's rooms to be connected with cloakrooms, while in reality only $33 \%$ of parents enrolled their children to a nursery in which such a connection was present. Over $50 \%$ of parents enrolled their children to a nursery with a functional system that did not meet their preferences. In terms of the direct connection of the children's room with a garden, analysis of the results showed that existing conditions in nurseries were in line with the preferences of parents. In contrast, $42 \%$ of parents chose a nursery for their children, in which each room was connected to a bathroom, while $66 \%$ of parents expected such a functional connection. The answer to the last question brought a similarly surprising result as in the case of the employee survey, and so $57 \%$ of 
parents enrolling children to a nursery in which the children's room was connected to a kitchen, and only $11 \%$ of the respondents preferred such a connection between the rooms.

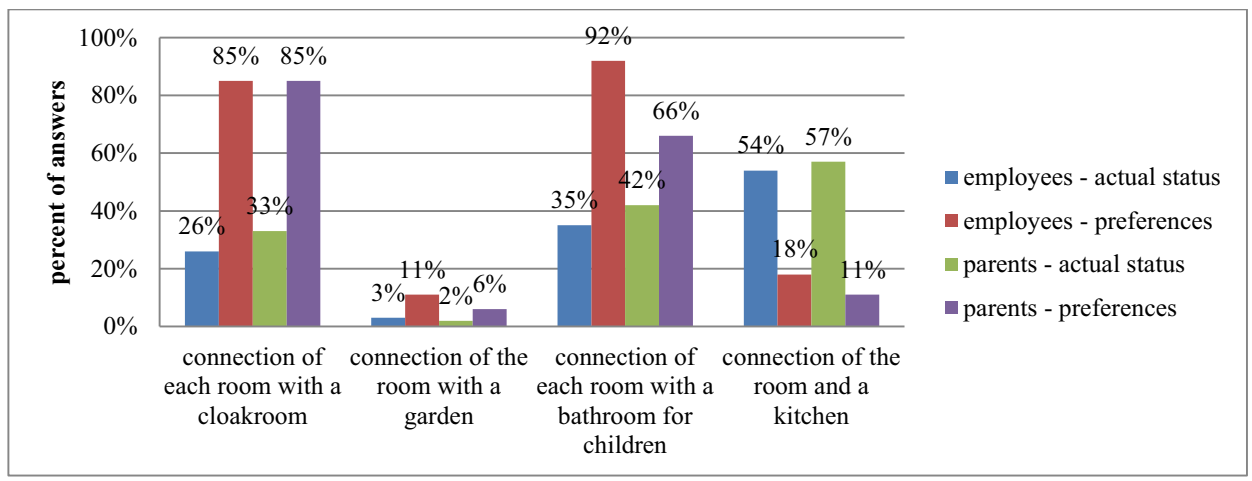

Fig. 1.Actual functional conditions in nurseries in relation to preferences

Comparing the preferences of parents and teachers, it can be concluded that both groups of respondents had similar expectations about the connection of the room with the cloakroom and consider it important, while the combination of the room with the kitchen and the room with the garden was considered to be of little significance. A discrepancy in the preferences of both groups occurred in the case of connecting the children's room with the bathroom for children, because it was less important to parents than it was to teachers.

\subsection{NURSERY SPACE IMPORTANCE ASSESSMENT}

The aim of the study was to determine the importance of particular rooms in nurseries to parents and teachers. The staff room turned out to be the least important to the parents, and the room for prams to the teachers, in both groups of respondents the room for children received the most votes (Fig. 2). 


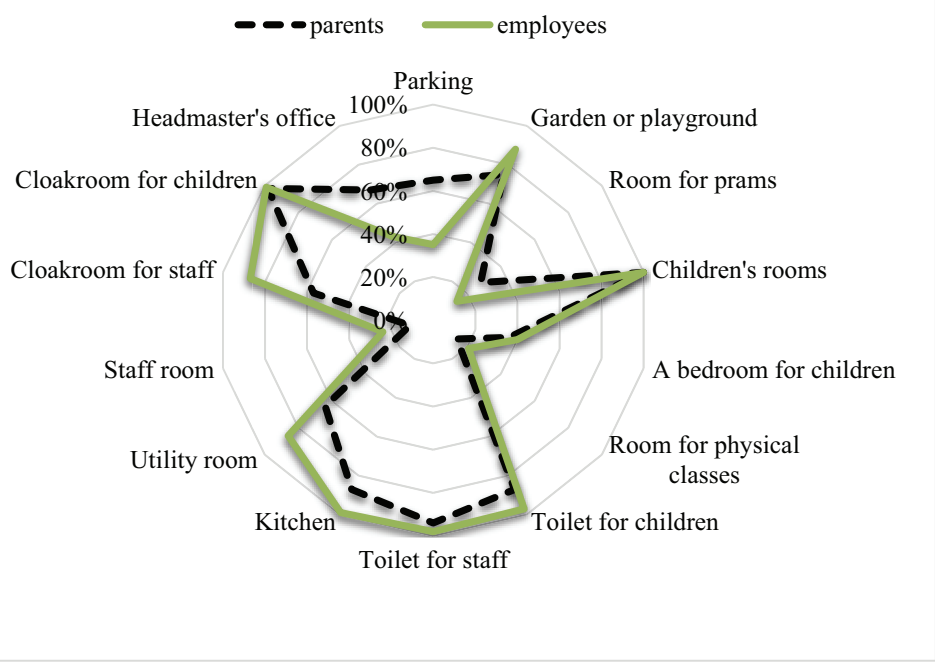

Fig. 2. Importance assessment of individual nursery spaces

\subsection{FINISHING MATERIALS USED IN NURSERY SPACES}

As the respondents identified the children's room as the most important room in the nursery, the next study concerned the analysis of finishing materials used on the floor in this room and user preferences in this field.

Later in the survey, respondents answered a question about the type of finishing materials that were used in rooms in the nursery facilities where they worked or that their children attended. The following question concerned the preferred type of flooring materials.

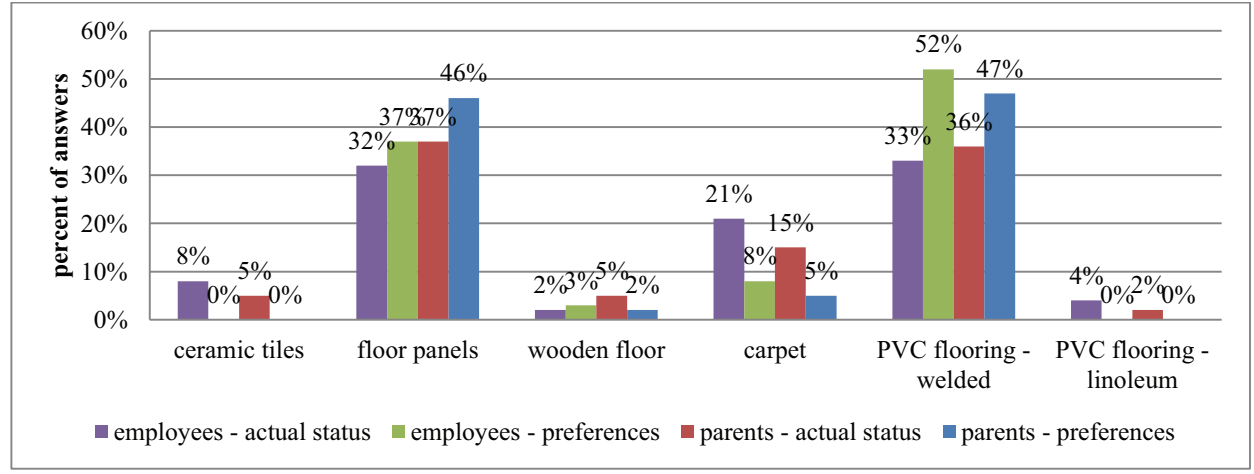

Fig. 3. Frequency of occurrence of individual flooring materials in children's rooms in relation to preferences 
The study demonstrated that floor panels, PVC flooring - welded, and carpet were the most frequently used finishing material (Fig. 3). In turn, the most preferred finishing materials by users were PVC flooring - welded, and floor panels, however, there was no clear support for carpet in this ranking. Why, then, do developers decide to use it despite it not being the most favoured material? Further research expanded knowledge of the preferred flooring materials used in nursery rooms based on individual parameters. Three most commonly used materials were evaluated: floor panels, PVC flooring and carpet.

Respondents rated the importance of individual parameters of flooring materials on a scale of 1-5 (5very important, 4- important, 3- significant, 2- somewhat important, 1- unimportant). The least important parameter for the respondents turned out to be a low price per $\mathrm{m}^{2}$ of material (average rating of 1.81). Another non-essential feature was low flammability (average rating of 1.87). The two parameters that received the highest ratings, i.e. that were the most important to the respondents, were good anti-allergic properties (average rating of 4.52) and ease of daily hygiene maintenance (average rating of 4.63). It can be said that hygiene and health were ranked higher by the respondents than the financial aspect or technical parameters affecting general safety, e.g. low flammability.

The next stage of the study featured the respondents reporting to what extent the given material met certain parameters, on a scale of 1-5 (5 excellent, 4 very good, 3 well, 2 poor, 1 very poor). The results have been shown on Fig. 4, Fig. 5 and Fig. 6. For floor panels, the low price per $\mathrm{m}^{2}$ of material parameter was rated as poor (average rating of 2.64), and therefore it was considered expensive, while the feature that was rated as excellent was its ease of obtainment on the market (average rating of 4.69). For PVC flooring, the low price per $\mathrm{m}^{2}$ of material parameter was also rated as poor (average rating of 2.49), which means that it was also considered expensive, and the low water absorption and impermeability were rated as excellent (average rating of 4.96). In the case of carpet, the good antiallergic properties parameter (average score of 1.37) was rated as poor, and therefore it was considered as an improper material for allergy sufferers, while non-slip surface (average rating 4.95) was rated as very good.

The parameter designations in Fig. 4, Fig. 5 and Fig. 6 are as follows:
a) high resistance to mechanical factors
b) low price per $\mathrm{m}^{2}$ of material
c) good anti-allergic properties
d) resistance to degradation over time
e) quick assembly
f) low installation price per $\mathrm{m}^{2}$ 
g) ease of obtaining on the market

h) low flammability

i) ease of daily hygiene maintenance

j) high thermal comfort

k) ease of professional disinfection

1) aesthetic properties

m) low water absorption and impermeability to water

n) non-slip surface

o) good acoustic insulation

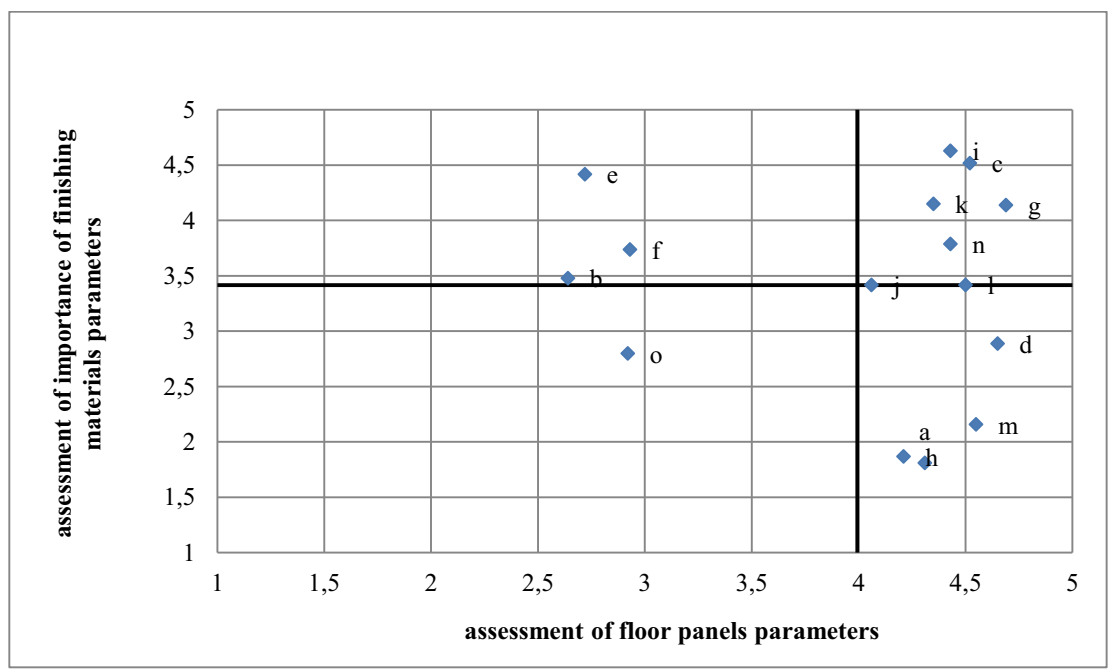

Fig. 4. Scatterplot of parameters for floor panels

In the upper right field there are features of the material that were rated as important. In the case of floor panels, these were: good anti-allergic properties, market availability, ease of daily hygiene maintenance, high thermal comfort, ease of professional disinfection, aesthetic properties. For PVC flooring this field featured such parameters as: good anti-allergic properties, ease of obtainment on the market, easy daily hygiene maintenance, ease of professional disinfection, aesthetic properties, non-slip surface. For carpet: low price per $\mathrm{m}^{2}$ of material, quick assembly, low installation price per $\mathrm{m}^{2}$, ease of obtainment on the market, high thermal comfort, aesthetic properties, non-slip surface. These features encourage customers to buy the materials and increase their satisfaction. 
By analysing the figures in a clockwise direction, in the lower right field we can find the features that the material has, but that were not seen as important to the customer. In the case of floor panels, these include: high resistance to mechanical factors, resistance to degradation over time, low flammability, low absorbability and impermeability to water. For PVC flooring: resistance to degradation over time, low flammability, low absorbability and impermeability to water, good acoustic insulation. Good acoustic insulation for the carpet.

In the bottom right field there are features that are the least important for the client and also those the material does not possess. In the case of floor panels this was good acoustic insulation. For PVC flooring: high resistance to mechanical factors. For carpet: high resistance to mechanical factors, resistance to degradation over time, low flammability, low absorbability and impermeability to water. The last field is the upper left corner. It contains important features that a material does possess, although to a very small degree. For floor panels these were: low price per $\mathrm{m}^{2}$ of material, quick assembly, low installation price per $\mathrm{m}^{2}$. For PVC flooring: low price per $\mathrm{m}^{2}$ of material, quick assembly, low installation price per $\mathrm{m}^{2}$, high thermal comfort, For carpet: good anti-allergic properties, ease of daily hygiene maintenance, ease of professional disinfection.

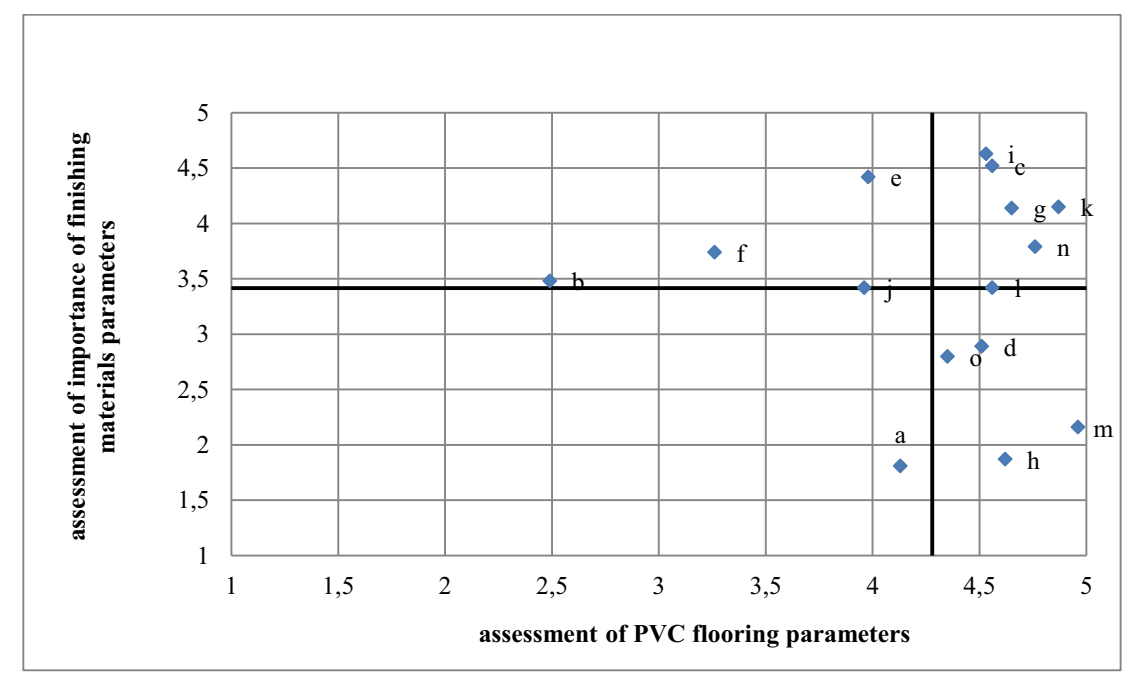

Fig. 5. Scatterplot of parameters for PVC flooring 


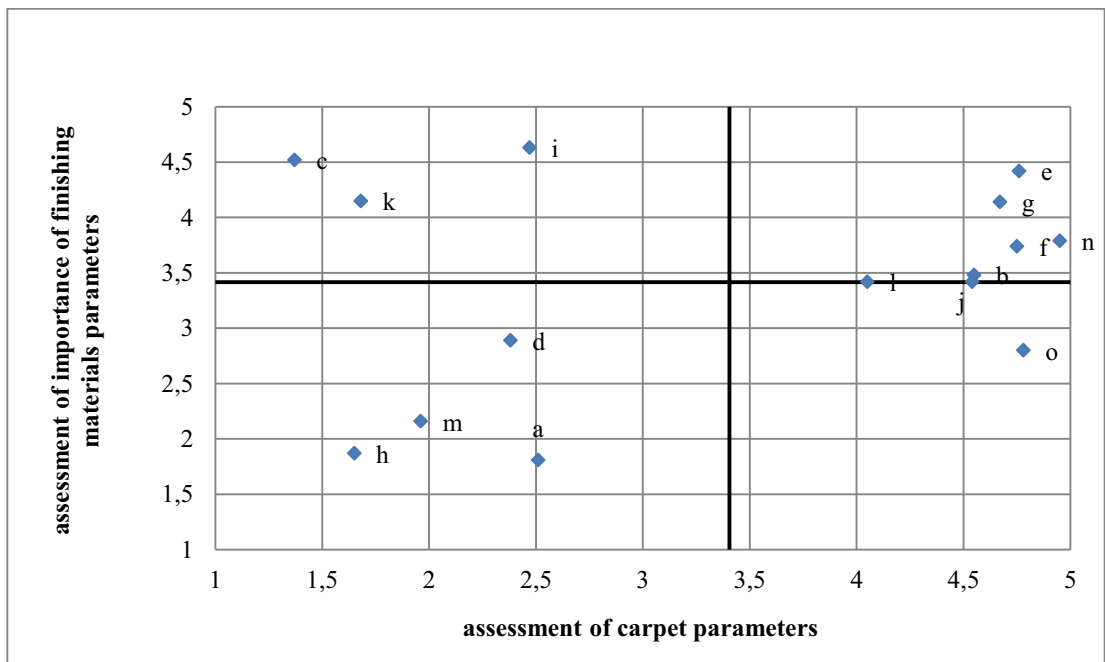

Fig. 6. Scatterplot of parameters for carpet

\section{CONCORDANCE OF RESPONDENTS' OPINIONS}

In order to recognize the obtained parameter importance ratings as credible and the degree to which each material meets the investigated parameters, the compliance of respondents' preferences was verified with the use of Kendall's coefficient of concordance [1]. In case of ties (parameters can be rated at the same level), the coefficient of concordance is expressed by the formula 5.1. [1].

$$
W=\frac{S}{S_{\max }-m T}=\frac{\sum_{j=1}^{p}\left(R_{j}-\frac{m(p+1)}{2}\right)^{2}}{\frac{1}{12} m^{2}\left(p^{3}-p\right)-m T}
$$

where:

$p$ - number of parameters, $m$ - number of respondents, $S$ - degree of actual relations between rankings, $S_{\max }$ - degree of relations in case of full compliance of rankings, $R_{j}$ - sum of ranks of $j$-th parameter (Eq 5.2 [1]), $T$ - correction for ties (formula $5.3[1]$ ).

$$
R_{j}=\sum_{i=1}^{m} a_{i j}
$$


where:

$a_{i j}$ - rank of $j$-th parameter (for $j=1,2, \ldots, p$ ) determined on the basis of the preferences of $i$-th respondent (for $i=1,2, \ldots, m$ ).

$$
\begin{gathered}
T=\sum_{i=1}^{m} T_{i} \\
T_{i}=\frac{1}{12} \sum_{k=1}^{K}\left(t_{k}^{3}-t_{k}\right)
\end{gathered}
$$

where:

$K$ - number of groups with the same rank $(k=1,2, \ldots, K)$ in the $i$-th ranking,

$t_{k}-$ number of identical tied ranks in the group.

The concordance coefficient takes on values from 0 to 1 , where 1 denotes full compliance of the rankings, and 0 a lack of compliance. The following interpretation of the degree of compliance was proposed on the basis of the value of this coefficient [13]:

- sufficient: for the range $0,20-0,40$,

- good: for the range $0,41-0,60$,

- plus good: for the range 0,61-0,80,

- very good: for the range $0,81-0,95$,

- ideal : for the range 0,96-1,00.

A statistical significance test of the concordance coefficient was also carried out, using the chisquared statistics. The null hypothesis $\left(H_{0}\right)$ with no relationship between series is rejected if the value $\chi_{r}^{2}$ (Eq. 5.5) is equal to or greater than $\chi_{\alpha}^{2}$, which is the value read from the chi-squared distribution tables for $d f=p-1$ degrees of freedom at a given significance level $\alpha[1](\alpha=0,05$ was assumed $)$.

$$
\chi_{r}^{2}=\frac{S}{\frac{1}{12} m p(p+1)-\frac{1}{p-1} T}
$$

Table 1 presents the results of respondent preference concordance verification. The obtained results indicate at least a good degree of concordance among the respondents taking part in the research. For all analysed parameter ratings, the null hypothesis may be rejected. The concordance of respondent opinions was not accidental. 
Table 1. Results of respondent opinion concordance verification

\begin{tabular}{|c|c|c|c|c|c|c|c|c|c|c|c|}
\hline $\begin{array}{l}\text { Analysed parameter } \\
\text { ratings }\end{array}$ & $p$ & $m$ & $S$ & $T$ & $W$ & Interpretation & $\chi_{r^{2}}^{2}$ & $d f$ & $\alpha$ & $\chi_{a}^{2}$ & $H_{0}$ \\
\hline $\begin{array}{l}\text { Parameter } \\
\text { importance }\end{array}$ & \multirow{4}{*}{15} & \multirow{4}{*}{200} & 5928215,0 & 6479,5 & 0,599 & $\begin{array}{c}\text { Good degree of } \\
\text { compliance }\end{array}$ & 1676,0 & \multirow{4}{*}{14} & \multirow{4}{*}{0,05} & \multirow{4}{*}{23,7} & Rejected \\
\hline $\begin{array}{c}\text { Floor panels } \\
\text { parameters ratings }\end{array}$ & & & 5102552,5 & 7921,5 & 0,531 & $\begin{array}{c}\text { Good degree of } \\
\text { compliance }\end{array}$ & 1485,8 & & & & Rejected \\
\hline $\begin{array}{c}\text { PVC flooring } \\
\text { parameters ratings }\end{array}$ & & & 4164560,0 & 11052, & 0,463 & $\begin{array}{c}\text { Good degree of } \\
\text { compliance }\end{array}$ & 1297,2 & & & & Rejected \\
\hline $\begin{array}{l}\text { Carpet parameters } \\
\text { ratings }\end{array}$ & & & 8526618,0 & 5097,0 & 0,838 & $\begin{array}{l}\text { Very good } \\
\text { degree of } \\
\text { compliance }\end{array}$ & 2345,1 & & & & Rejected \\
\hline
\end{tabular}

\section{CONCLUSIONS}

In the case of the expectations held by the parents and teachers regarding the function of the children's room, the functional arrangement of space in the nurseries and finishing materials applied, only a slight difference may be noticeable. Analyses have proven that the requirements of these two groups tend to be similar. Thanks to this consistency, when planning a nursery project one can take into account the expectations of both groups at the same time.

Based on the research, guidelines can be defined that will allow for the establishment of an optimal nursery facility. The study has demonstrated that:

- $\quad$ children's rooms should be connected with a cloakroom and a bathroom

- the least important rooms in nursery facilities are the staff rooms, the rooms for additional activities and pram rooms.

- rooms that should not be omitted include: the children's room, cloakroom, toilet and kitchen

- the flooring of children's rooms should be equipped with panels or PVC flooring, depending on the type of parameters that are important for the particular project and the decision-maker's preferences.

Nursery projects should be carried out in close cooperation not only between their designers (civil engineers and interior architects) and contractors, but should also be adequate to the expectations of the developers and users, in accordance with the applicable administrative procedures in this regard. 


\section{REFERENCES}

1. P. Cabała, "Zastosowanie współczynnika konkordancji w pomiarze zgodności ocen ekspertów" Przegląd Statystyczny 57(2-3): 36-52, 2010

2. J. Choi, C. Chun, Y. Sun, Y. Choi, S. Kwon, C. G. Bornehag, J. Sundell, “Associations between building characteristics and children's allergic symptoms-a cross-sectional study on child's health and home in Seoul, South Korea", Building and Environment 75: 176-181, 2014

3. W. Grabowska, „Procedury administracyjne i analiza techniczno-funkcjonalna obiektów żłobkowych" (Administrative procedures, technical and functional analysis of nurseries), master thesis, supervisor: E. Radziszewska-Zielina, Cracow University of Technology, Polnand, 2018

4. B. Kłos, J Szymańczak, „Instytucje opieki dla dzieci w wieku do lat 3 w Polsce”, Analizy BAS 8(97), 2013

5. W. Kramarz, „Informator krakowskiej rodziny”, Kraków: Urząd Miasta Krakowa, 2017

6. J. Krentowski, P. Knyziak, "Evaluation Aspects of Building Structures Reconstructed After a Failure or Catastrophe”, WMCAUS 2017, IOP Conf. Series: Materials Science and Engineering 245: 032099, 2017

7. M. Ksiażek, P. Nowak, S. Kivrak, J. Roslon, L. Ustinovichius, „Computer-aided decision-making in construction project development” Journal of Civil Engineering and Management, 21(2), 248-259, 2015

8. S. S. J. Neill, E. J. M. Denham, "The Effects of Pre-school Building Design”, Educational Research 24(2): 107111,1982

9. B. Nilsson, B. Peterson, G. Holden, C. Eckert, "Design Med Omtanke: Participation and sustainability in the design of public sector buildings", Design studies 32(3): 235-254, 2011

10. B. Nowogońska, J. Cibis, "Technical problems of residential construction” WMCAUS 2017, IOP Conf. Series: Materials Science and Engineering, 245: 052042, 2017

11. E. Radziszewska-Zielina, "Assessment methods of partnering relations of Polish, Slovak and Ukrainian construction enterprises with the use of fuzzy logic", Archives of Civil Engineering 57(1): 87-118, 2011

12. E. Radziszewska-Zielina, B. Szewczyk, "Supporting partnering relations management in construction projects' implementation using AHP and Fuzzy AHP”, Procedia Engineering 161: 1096-1100, 2016

13. A. Stabryła, „Zarządzanie strategiczne w teorii i praktyce firmy”, Warszawa: Wydawnictwo Naukowe PWN, 2005

14. Ustawa z dnia 4 lutego 2011r. - o opiece nad dziećmi w wieku do lat 3 (Dz.U. 2011 Nr 45 poz. 235)

15. website http://krakow.pl/aktualnosci/216527,34,komunikat,wiecej_miejsc_w_zlobkach_z_dofinansowaniem.html

\section{LIST OF FIGURES AND TABLES:}

Fig. 1. Actual functional conditions in nurseries in relation to preferences

Rys. 1. Rzeczywiste warunki funkcjonalne panujące w żłobkach w stosunku do preferencji

Fig. 2. Importance assessment of individual nursery spaces

Rys. 2. Ocena ważności poszczególnych pomieszczeń w żłobkach

Fig. 3. Frequency of occurrence of individual flooring materials in children's rooms in relation to preferences Rys. 3. Częstość występowania poszczególnych materiałów wykończeniowych na podłogach w salach w stosunku do preferencji

Fig. 4. Scatterplot of parameters for floor panels

Rys. 4. Wykres rozrzutu parametrów paneli podłogowych

Fig. 5. Scatterplot of parameters for PVC flooring

Rys. 5. Wykres rozrzutu parametrów wykładziny PVC

Fig. 6. Scatterplot of parameters for carpet

Rys. 6. Wykres rozrzutu parametrów wykładziny dywanowej

Tab. 1. Results of respondent opinion concordance verification 
Tab. 1. Wyniki weryfikacji zgodności opinii respondentów

\section{MARKET RESEARCH CONCERNING FUNCTIONAL AND MATERIAL SOLUTIONS EMPLOYED IN NURSERY FACILITIES}

Keywords: market research, nursery facilities, functional and material solutions, finishing materials for floors

\section{AbSTRACT:}

In Poland, nursery capacity does not meet the growing demand, which in practice results in a reduction of technical requirements for such facilities. As a result, many non-functional child care facilities for children up to the age of three have been established. Extreme cases include facilities that do not meet the provisions of the construction law, good design practice, not to mention the expectations of the employees of these institutions and the parents of children attending them. Badly designed nurseries are, primarily, a problem for their youngest users. This state of affairs can be blamed on the low level of knowledge in this area, as well as few available studies on topics associated with nursery facilities that can familiarise readers with legal aspects, administrative procedures, examples of good functional and material solutions of said facilities, in addition to there being little information about the needs and preferences of people directly interested in this topic. The aim of the article was to analyse the expectations and preferences of users of nursery facilities in the field of functional and material solutions. Based on a survey conducted among employees of nurseries and parents enrolling their children to these institutions, guidelines were defined that would allow for the design of an optimal nursery facility meeting market expectations.

In the case of teachers' and parents' expectations regarding the function and space of the children's room, the functional arrangement of rooms in nurseries and finishing materials used, the results of the research differed slightly. Thanks to this consistency, when planning a nursery project, the expectations of both groups can be taken into account simultaneously. Fig. 3 presents respondents' answers to a question about the type of finishing materials that were used in rooms in the nursery facilities where they worked or that their children attended as well as respondents preferences in this regard.

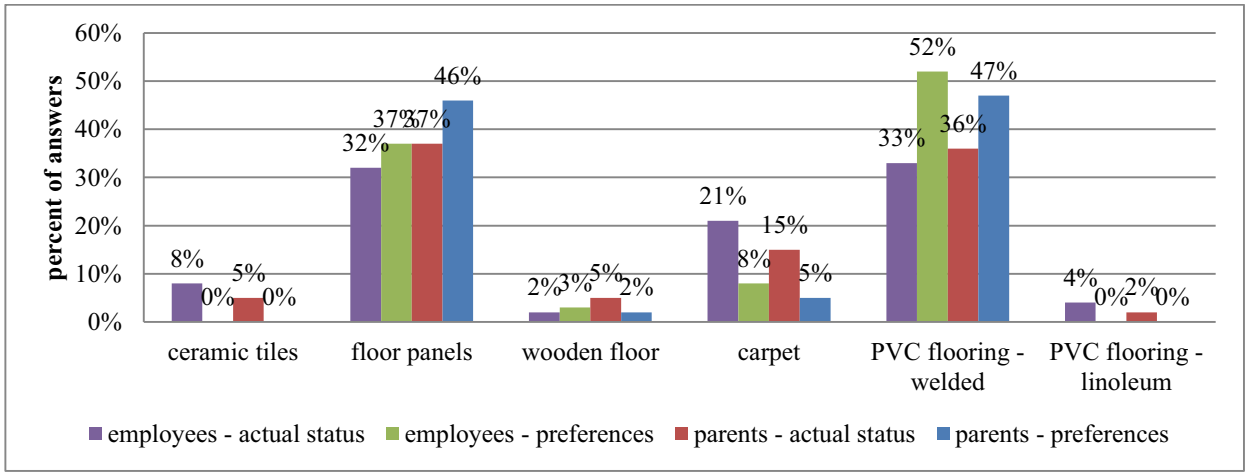

Fig. 3. Frequency of occurrence of individual flooring materials in children's rooms in relation to preferences 
Studies have shown that: a children's room should be connected with a cloakroom and a bathroom for children; the least important rooms in the nursery were the staff room, the room for additional activities and the pram room; rooms that cannot be omitted include: the children's room, the cloakroom, toilet and kitchen; It is best to finish the floors of children's rooms with panels or PVC flooring, depending on the type of parameters that are important for a particular project and the decision-maker's preferences.

Nursery facility projects should be carried out in close cooperation not only between designers (civil engineers and interior architects) and contractors, but also should be adequate to the expectations of developers and users, in accordance with the applicable administrative procedures in this regard.

\section{BADANIE RYNKU W ZAKRESIE ROZWIĄZAŃ FUNKCJONALNO-MATERIALOWYCH OBIEKTÓW ŻLOBKOWYCH}

Słowa kluczowe: badanie rynku, obiekty żłobkowe, rozwiązania funkcjonalno-materiałowe, materiały wykończeniowe podłóg

\section{STRESZCZENIE:}

W Polsce liczba miejsc w żłobkach nie zaspakaja rosnącego zapotrzebowania, co w praktyce spowodowało zmniejszenie wymagań lokalowych dla tego typu obiektów. W wyniku tego powstało wiele niefunkcjonalnych miejsc opieki nad dziećmi w wieku do lat trzech. Skrajnymi przypadkami są obiekty niespełniające przepisów prawa budowlanego, dobrej praktyki projektowania, nie wspominając o zaspokojeniu oczekiwań pracowników tych instytucji oraz rodziców dzieci do nich uczęszczających. Źle zaprojektowane żłobki są przede wszystkim problemem dla ich najmłodszych użytkowników. Taka sytuacja ma miejsce m.in. ze względu małą wiedzę w tym zakresie, nieliczne dostępne opracowania o tematyce żłobkowej przybliżające zarówno przepisy prawne, procedury administracyjne, przykłady dobrych rozwiązań funkcjonalno-materiałowych obiektów żłobkowych jak i nieliczne informacje o potrzebach i preferencjach osób bezpośrednio zainteresowanych tym tematem. Celem artykułu była analiza oczekiwań i preferencji użytkowników obiektów żłobkowych w zakresie rozwiązań funkcjonalno-materiałowych. Na podstawie przeprowadzonych badań opinii pracowników żłobków i rodziców oddających dzieci pod opiekę tych instytucji określono wytyczne, które pozwolą na zaprojektowanie optymalnego obiektu żłobkowego, odpowiadającego oczekiwaniom rynku.

W przypadku oczekiwań nauczycieli i rodziców dzieci dotyczących funkcji i powierzchni sali dla dzieci, układu funkcjonalnego pomieszczeń w żłobkach i stosowanych materiałów wykończeniowych, wyniki badań nieznacznie się od siebie różniły. Dzięki tej spójności planując inwestycję żłobkową można uwzględnić oczekiwania obu grup jednocześnie. Rys. 3 przedstawia odpowiedzi respondentów na pytanie, jakie materiały wykończeniowe były stosowane w salach żłobkowych w placówkach, w których pracowali lub do których uczęszczały ich dzieci, jak również preferencje respondentów w tym zakresie. 


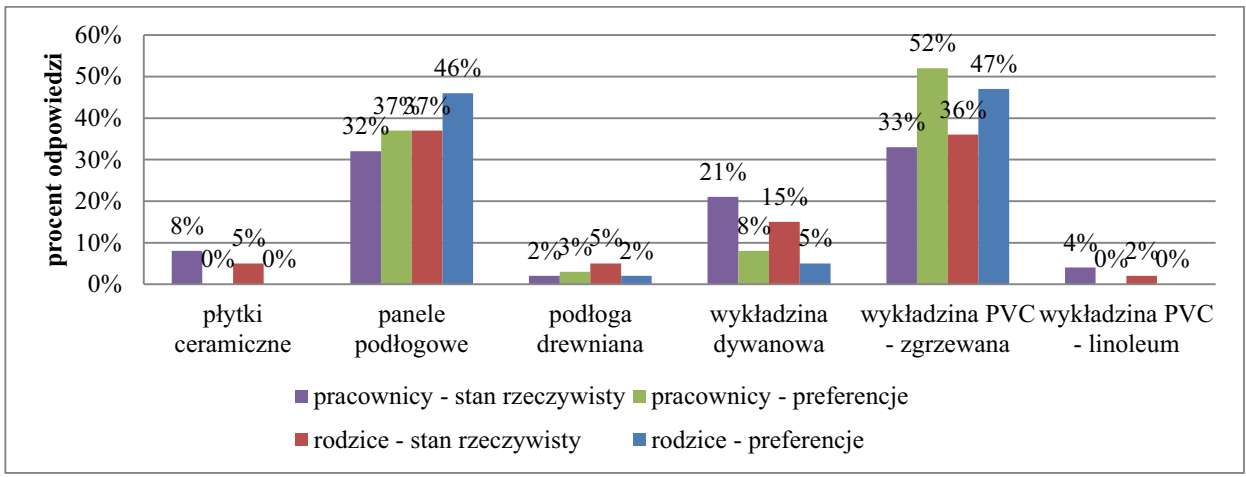

Rys. 3. Częstość występowania poszczególnych materiałów wykończeniowych na podłogach w salach w stosunku do preferencji

Badania wykazały, że: sala dla dzieci powinna być połączona z szatnią i łazienka dla dzieci; najmniej istotnymi pomieszczeniami w żłobku są pokój nauczycielski, sala do zajęć ruchowych i pomieszczenie na wózki; pomieszczeń, których nie może zabraknąć są: sala dla dzieci, szatnia, toaleta i kuchnia; salę zabaw najlepiej wykończyć panelami lub podłogą PVC, w zależności od rodzaju parametrów, które są istotne dla danej inwestycji oraz preferencji decydenta. Inwestycje żłobkowe powinny być realizowane w ścisłej współpracy nie tylko projektantów (konstruktorów i architektów wnętrz) oraz wykonawców, ale również powinny być adekwatne do oczekiwań inwestorów i użytkowników, zgodne z obowiązującymi procedurami administracyjnymi w tym względzie. 